\title{
Nursing team's conceptions about the families of hospitalized children
}

\author{
As concepções da equipe de enfermagem frente à família da criança hospitalizada \\ Concepciones del equipo de enfermería ante la familia del niño hospitalizado
}

\section{Isabela Fornerolli de Macedo',II, Tania Vignuda de Souza', Isabel Cristina dos Santos Oliveira', Sylvia Alves Cibreiros"', Rita de Cássia Melão de Morais', Rosana Fidelis Coelho Vieira'}

'Universidade Federal do Rio de Janeiro, Anna Nery School of Nursing, Postgraduate Program in Nursing. Rio de Janeiro, Brazil.

"Universidade Estadual do Rio de Janeiro, School of Nursing, Department of Mother and Child health. Rio de Janeiro, Brazil.

How to cite this article:

Macedo IF, Souza TV, Oliveira ICS, Cibreiros AS, Morais RCM, Vieira RFC. Nursing team's conceptions about the families of hospitalized children. Rev Bras Enferm [Internet]. 2017;70(5):904-11. [Thematic Edition "Good practices and fundamentals of Nursing work in the construction of a democratic society"] DOI: http://dx.doi.org/10.1590/0034-7167-2016-0233

Submission: 06-29-2016 Approval: 01-18-2017

\begin{abstract}
Objectives: to describe nursing team care and discuss the nursing team's conception of companion families of hospitalized children. The study was based on the theoretical framework of Collière's theory of nursing care identity. Method: this was a qualitative study with 14 members of a nursing team, conducted through an unstructured group interview. Thematic data analysis was employed. Results: habitual and repair care was delegated to families, regardless of the child's clinical condition. Final considerations: the team's official discourse about the families of hospitalized children, as recommended by the literature, refers to the family's alterity and participation in care provision, with sights on discharge and defending family participation as beneficial to children. In practice, however, the nursing staff makes concessions about the presence of chaperoning families and delegates care.
\end{abstract}

Descriptors: Nursing Team; Hospitalized Child; Family; Pediatric Nursing; Nursing Care.

\section{RESUMO}

Objetivos: descrever os cuidados da equipe de enfermagem e discutir as concepções da equipe de enfermagem frente à família acompanhante da criança hospitalizada. O referencial teórico está vinculado à identidade do cuidado de enfermagem de Collière. Método: Estudo qualitativo com quatorze membros da equipe de enfermagem, utilizando a técnica de entrevista não diretiva em grupo. Foi realizada análise temática dos dados. Resultados: os cuidados habituais e de reparação prestados à criança estão sendo delegados à família, independentemente da situação clínica da criança. Considerações finais: o discurso oficial da equipe de enfermagem frente à família acompanhante da criança hospitalizada, preconizado pela literatura, refere-se à alteridade e à participação da família nos cuidados à criança, prevendo sua alta e justificando a participação como benéfica para a criança. Em contrapartida, na prática, a enfermagem faz concessões sobre a permanência da família e delega os cuidados. Descritores: Equipe de Enfermagem; Criança Hospitalizada; Família; Enfermagem Pediátrica; Cuidados de Enfermagem.

\section{RESUMEN}

Objetivos: describir los cuidados del equipo de enfermería y discutir las concepciones del equipo ante la familia acompañante del niño hospitalizado. El referencial teórico está vinculado a la identidad del cuidado de enfermería de Collière. Método: estudio cualitativo, con catorce miembros del equipo de enfermería, utilizando técnica de entrevista no directiva en grupo. Fue realizado análisis temático de los datos. Resultados: los cuidados habituales y de reparación brindados al niño están siendo delegados en la familia, independientemente de la situación clínica del niño. Consideraciones finales: el discurso oficial del equipo de enfermería recomendado por la literatura ante la familia acompañante del niño hospitalizado hace referencia a la otredad y a la participación de la familia en el cuidado del niño, previendo su alta y justificando la participación como benéfica para el niño. En contrapartida, en la práctica, la enfermería hace concesiones respecto de la permanencia familiar y delega los cuidados.

Descriptores: Grupo de Enfermería; Niño Hospitalizado; Familia; Enfermería Pediátrica; Atención de Enfermería. 


\section{INTRODUCTION}

Nursing care in pediatric inpatient units involves and requires partnerships with the child's family and transcends patient treatment. Nursing teams should not limit themselves to performing technical procedures, which contribute to the child's recovery, but also assist families with their doubts, support their initiatives, and provide constant encouragement for them to develop their own care, considering physical, socioeconomic, cultural, and spiritual contexts ${ }^{(1)}$.

Family is considered a complex area of knowledge, especially in the pediatric hospital setting. It is necessary to understand that the hospital is not the family's natural setting, and instead of making them adapt to this new environment, they need receive help to organize their daily life to cope with the impact of the child's hospitalization.

Each member of the nursing team has their own conception about the families of hospitalized children, which interferes in the development of care practices, either including or excluding families from practical activities. "In what refers to nursing care, family must be considered an essential part of the care process"

The present study was based on the theoretical framework presented by Collière (1999) on nursing care identity. This approach distinguishes between two types of care: habitual care, or activities associated with the maintenance and continuity of life, such as hydration, feeding, evacuation, movement, and displacement, and everything that contributes to human development and survival; and repair care, which is aimed at treatment, fighting and combatting disease, and investigating causes ${ }^{(3)}$.

"The meaning of cure has insidiously invaded care and has dressed itself in it"(3). Thus, the cure of a given disease absorbs care in such a way that, in health institutions, care primarily covers that which lies within the scope of cure, or restoration, making all daily and habitual care an accessory of minimal importance, even though it is essential to maintaining life every day and enabling patients to fight against disease. Care cannot be limited to the illness, regardless of how severe or benign its treatment, and it can never replace the mobilization of the life capacities that represent care ${ }^{(3)}$.

The way in which the nursing team conceives the families of hospitalized children influences their attitude and stance before nursing care. Thus, learning about this conception can clarify how pediatric nursing develops its care in pediatric inpatient units.

Considering the above, the objectives of this study were to describe nursing care related to the families of hospitalized children and the conceptions held by the nursing team about the families of hospitalized children.

\section{METHOD}

\section{Ethical aspects}

This study was approved by the research ethics committee of the proposing and the co-participating institutions and the researchers abided by the ethical precepts recommended by Resolution 466/12 of the Brazilian National Health Council( ${ }^{(4)}$ about research with human subjects.

To ensure anonymity, participants were identified with the initials of their professional category followed by Arabic numbers.

\section{Study type and location}

This was a qualitative study with 14 members of a nursing team working in the pediatric inpatient unit (PIU) of a public university hospital located in the city of Rio de Janeiro, Brazil. The inclusion criterion was being a nursing professional who had worked at the PIU for at least a year.

\section{Data collection and organization}

Data were gathered through unstructured group interviews. This type of interview is based on the client-centered psychotherapy approach initially developed by Carl Rogers. According to this technique, participants are encouraged to discourse freely on a given topic, and as they speak the interviewer pays attention to their verbal and nonverbal communication, helping and stimulating free expression. The discussion is guided by questions about themes of interest to the researchers, and should include three to five participants ${ }^{(5)}$.

The themes used in the interviews were: the family of the hospitalized child, the family's presence in the hospital, family participation in health care provision, and nursing team's relationship with families.

The interviews occurred between September and November 2013 and were previously scheduled with the study participants. The participants were taken to a previously reserved room in the PIU and after reading and signing a free and informed consent form data collection began. The interview themes were displayed on the wall and presented and read to the group. The participants were then instructed to talk freely about the themes presented, with no predetermined sequence. All the interviews were recorded and later transcribed. The number of interviews was determined by theoretical saturation, when no new elements emerged in the participant's discourse ${ }^{(6)}$.

\section{Data analysis}

The collected data were processed using thematic analysis, a methodology composed of pre-analysis, exploration of the material, and processing of the results ${ }^{(7)}$. Pre-analysis consists of freely reading the material to obtain an overall idea of its content, capturing particularities in the material and choosing forms of initial classification. When exploring the material, researchers distribute text excerpts, phrases or fragments within a classification scheme, read the material while dialoguing with text excerpts and regroup parts of the text according to the emerging themes. On processing/interpreting the results, the objectives of the study are coordinated with the theoretical content and the empirical data ${ }^{(7)}$.

When analyzing the interviews, the following thematic units emerged: care provision to the child; interaction between the nursing team and families; and families with the subject of care. These themes represent the topics of analysis presented in the results.

\section{RESULTS}

Of the fourteen nursing team members who worked at the pediatric inpatient unit, eight were nursing technicians and six were nurses. The nursing technicians were between 20 and 56 years old, with time since degree ranging between one year and seven months to 29 years. Of these participants, six were day shift 
workers and two worked the night shift. Time of experience in pediatrics varied from 1 to 29 years, and four had more than one job. Two nursing technicians had undergraduate nursing degrees and one had a graduate degree in clinical oncology and surgical nursing. Five technicians reported having participated in professional development courses offered by the institution and two of them reported having participated in courses at scientific events over the last five years.

The nurses were between 24 and 43 years old. Time since degree ranged from one to 15 years. Two of the nurses worked day shifts, one worked the afternoon shift, and three were night shift nurses. Experience in pediatrics varied from two to 15 years, and all of them had other jobs. Five nurses had graduate degrees, of which three were in neonatology and two in occupational health nursing. It is worth noting that none of the nurses were specialized in pediatrics. Regarding professional development courses or participation in scientific events in the field of pediatrics over the last five years, five nurses reported participating in courses provided by the institution.

The thematic units that emerged from the nursing team's declarations were grouped into three topics of analysis:

\section{Families and the nursing team: sharing care provision for the hospitalized child}

The participants highlighted the nursing team's responsibility for care provision during the child's hospitalization:

I don't think parents are responsible during the child's hospital stay, at most we can provide guidance and assist them. There are a lot of things that we observe and I think it's wrong when parents are made responsible for that care, when the child's hospitalized [...]. (N 1)

[...] If you exempt yourself from the responsibility and place the load on the family [...] They are already carrying a burden, if coupled with our burden they become agitated, stressed people and this often ends in conflict. (N 2)

We need to know how to share [...] but this does not mean exempting ourselves from our responsibilities and passing them on to the mother just because she knows how to do it, I'm not going to do that and let her do it. No way! (NT 1)

The members of the nursing team considered that family participation in care provision is necessary, as shown in these excerpts:

[...] Actually, we need to involve parents in this care as well, it helps us, gives us a sense of security and so we feel more confident. (N 1)

[...] I think it's very important to bring family members close to what you are doing, close to the care you are giving the child [...]. (N 5)

On the other hand, N3 considered that the nursing team must establish a prior agreement regarding family participation in care provision, especially during the night:

[...] What happens is that people wake up the mother to hold the nebulizer and administer food [...] I know they do this, especially at night, because there are fewer people [...] I think it all comes down to conversation: look mother, I need your help [...] sometimes I'll need you to collaborate with me in the sense of holding up the nebulizer, but not all the time! (N 3)

Another nurse reported a situation involving diaper changes in the PIU:

[...] The child was admitted to the PIU, stayed two days here, and all the care was imposed on the mother. She had never done any of it with the child [...] I only realized this when I saw her changing her diaper [...] the child was on her back, with the head rest completely flat [...] I saw her from my station and the girl had gone black [...] I told her she couldn't do that, her diaper had to be changed on her side and the head rest elevated and she turned to me and said: I didn't know that. That was a wake-up call, because I realized I hadn't instructed her either [...]. (N 3)

In contrast, another interviewee considered diaper changes as an act inherent to maternal care:

I see diaper changes as a normal part of the routine; mothers change diapers at home, why is it exactly that they can't change them in the hospital? (NT 2)

The nurse promptly continued to say that diapers can be changed by family members, however, it is up to nurses to evaluate its contents:

[...] It's not that family members can't change diapers, but the child is hospitalized [...] so if the grandmother, or any other person changes the diaper and throws it out, either I have to go through the trash to evaluate the feces and urine or I have to rely on what the chaperone tells me [...]. (N 3)

In contrast, NT 2 considered that family members should verify urine excretion and communicate this information to help the nursing team:

[...] Chaperones are here to take notes on diuresis and things like that [...] and pass it on to us. (NT 2)

The group considered that family presence is beneficial to the child's emotional needs during hospitalization:

[...] We need to understand that chaperones are there to ensure that children have the least traumatic hospital stay possible [...]. (N 3)

When children are with someone familiar to them, they are much calmer, they feel more confident [...]. (NT 3)

I believe that the mother's presence calms them [...] Look at the difference with A. when his mother is here, he's much calmer [...]. (N 4)

The nursing team mentioned the need to provide family members with guidance about hospital discharge, as they will have to continue care provision at home, as reported below:

We have to realize that this child will be going home later on and will probably be cared for by that family member [...] we 
have to teach them about the necessary care [...]. (N 5)

[...] When a child is discharged, and goes home, who takes care of them? The mother. So, it's good for her to know how to handle devices, how to suction. (NT 1)

The family's presence in the pediatric inpatient unit: (im) possibility of interaction between family and nursing team in the child's care.

Regarding threatening and aggressive behaviors of family members with the team, three participants declared the following:

[...] Some people are very ignorant in the literal sense of the word, sometimes you want to interact with them, but you can't, it's no use [...]. (N 1)

[...] Some families come in for the first time in a terrible mood, mistreating everyone around them because their child is going to be hospitalized [...]. (N 6)

[...] There were days when the mother said she was going to hit the nurses, she was upset [...]. (NT 5)

One interviewee stated that aggressive behavior is justified depending on how the family is approached:

[...] I think it all depends on how you approach them and ask questions, request information. Some families aren't up for conversation, they don't let us in. Then it's a bit harder, but not impossible! (NT 8)

On the other hand, a nursing technician highlighted respectful behaviors displayed by some families:

I see both sides of the issue: some families also respect the nursing staff [...]. (NT 8)

The nurses reported reacting to the aggressive behavior from families:

Some mothers make you not want to enter the child's box. The child is not to blame, but you get there and are mistreated and so you do your job mechanically, you do what you have to do and goodbye, and that's not good! (NT 1)

I go in there and do only what I have to do, only what the child needs [...] I administer medication on schedule, I go there and give them their scheduled medication, check vitals [...]. (NT 2)

What I feel is that many times, we receive gratuitous aggression, sometimes it's easier to care for a child who is alone than when they are with their family. I'm afraid of even getting close [...]. It's such a difficult relationship! (NT 4)

The care given to the child tends to be mechanical, as demonstrated by participant NT 3:

[...] I think you have to interact with the family members [...] with the child, to provide such care, so that it's not merely mechanical, or an obligation [...] At least I don't like to do what is strictly necessary, I like to be affectionate, play with them [...]. (NT 3)
The participants expressed the importance of informing family members about procedures before initiating care:

The nursing team's relationship with the family is everything! You need to have it, but sometimes it's not there. They feel safer with professionals who interact than with professionals that go in and do things and provide no explanations [...]. (N 1)

The participants also stated that length of hospital stay negatively impacts the family-nursing team relationship:

The family's stay in the hospital is also complicated, the longer the stay the more complicated [...]. (N 1)

[...] I think it's complicated when families spend too much time in the hospital. There are two situations: some families focus only on their child and some spread out and think they have to take care for other people's children as well [...]. (N 6)

There were also reports of affectionate bonds established with hospitalized children:

[...] When I like the child, it seems to draw me in and I spend more time there [...]. (NT 2)

[...] There was this one patient, A., I can't even talk about her [...] I loved that girl so much [...] It's impressive how I bonded with her. (NT 3)

\section{The identity of nursing team care for families of hospital- ized children}

Care directed at families includes orientation both about the child's nursing care and the hospital routine, as emphasized by the participants:

He entered the ward and received no guidance about what was going to happen [...], after all, the child is his relative and that isn't always interpreted positively by nursing professionals. (N 5)

[...] When children are admitted, we need to meet with their families and explain everything that will be done [...] We need to have this conversation [...] so that the relationship between mothers and the team can be better [...]. (NT 6)

Interviewee NT 7 reported that lack of guidance or the way information is conveyed to the family can generate lack of confidence:

Often, they don't tell the mother what is happening, or they'll tell her haphazardly. She feels a bit of carelessness for what is happening [...]. (NT 7)

Regarding care for the family, the participants expressed empathy, reporting many situations that can stress families, such as: exhaustion because there is no one to take turns with during the hospital stay; feeling indisposed; absence of family members during the stay; and long months in the hospital:

We need to think like this: this mom is alone, she has no one to take turns with. Gosh, she must be tired. She may feel indisposed. Like all of us. (N 1) 
One day she wasn't feeling well, so I said, "No, let me do it [...] I'll give him a bath, you don't need to get him out of bed. (NT 1)

[...] We need to take care of both of them, the hospitalized child and their companion [...] In addition to the individual who has been hospitalized, there is also the companion. It's a double type of care [...]. (N 3)

[...] I see it this way, if I get sick of staying here 12 hours straight, because the shift was hard [...] Imagine her, who has been here for 3 months already, I think. (N 4)

One participant complemented the topic with the importance of the nursing team practicing empathy toward the family, understanding the difficult nature of their situation:

[...] I think we need to put ourselves a bit in their shoes too, it must be hard. (NT 8)

The interviewees also indicated the need for families to receive psychological support:

[...] We observed that the child's father had stopped coming, that she's alone in the hospital [...] and it's a series of things that should be addressed by whom? Psychologists. But who is in there with them the whole time? Nurses. (N 3)

Sometimes we even play the role of psychologists [...] Sometimes they just want to talk and just want someone to listen. (NT 8)

Regarding the individuality of each case or situation, the participants indicated making some concessions such as: allowing families to eat in the child's unit; taking blood samples for family members in the pediatric sector; celebrating the child's birthday with other family members:

Parents are not allowed to eat in the child's cubicle, some teams allow it and others don't. The routine needs to be followed, in case of any changes management must be notified. We can make exceptions, but they must be communicated to management and justified [...]. ( $\mathrm{N} 1)$

[...] She was pleased, she fasted and I took her blood sample and sent it to the lab and told her to get the result and that everything was underway for her to do the surgery. If we interact well, things will flow well. (NT 1)

[...] It makes the family happy! [...] Even though each shift has its own way of conducting things. I don't know if my colleague would allow a cake to celebrate the child's seven-month birthday, but I think they have the right to have the cake. The ward isn't full, it's not going to interfere with our work [...]. (N 6)

One nursing technician reported that the relationship with professionals improve when concessions are made:

[...] I think that the hospital environment is a sick environment. It doesn't make a good impression, so when you start making some exceptions, which for us are simple things, it means a lot to the family [...]. (NT 7)

\section{DISCUSSION}

Most participants conceived families as an important element in the development of habitual and maintenance care of hospitalized children. The discourse found in the literature justifies this conception, as families have been shown to provide emotional security to their children and help nursing teams, especially considering staff shortage. In practice, care is delegated to families regardless of the child's clinical situation and the use of technological devices, ignoring the singularity of each child and considering that some types of care are naturally performed at home. However, in the hospital setting these care actions should be the nursing staff's responsibility, as they demand technical and scientific knowledge.

Singularity or individuality is considered one of the principles of nursing care identity. Identity is a form of individualization within a network of belonging. Thus, nursing care needs to find its individuality with relation to the general network to which it belongs, the care network ${ }^{(3)}$.

It is worth mentioning that habitual and life-maintaining care present other characteristics when performed by families in the PIU, as they occur in a setting that is neither the family's nor the child's. Thus, the family is not equipped or technically qualified to develop such care in the hospital environment, especially during their first hospital stay and according to the specificities of the child's clinical case.

Regardless of the child's clinical condition or the family's preparation, a study addressing the relationship of the family/ companion and nursing team during the child's care in the hospital found that such care tends to be delegated to family members, and therefore "the uncommon becomes common, disregarded by the nursing team"(1).

The family is understood as an agent in the work process, and not a subject that also requires care in the hospital. They do not participate in decision making, but perform care that lies under the nursing staff's attributions ${ }^{(8)}$. However, the family's participation in care provision in hospital inpatient units is a competence that needs to be developed by nursing and health teams, flexibilizing regulations and routines ${ }^{(9)}$.

Repair care was also delegated to the family and is justified by hospital discharge, as the family will have to perform care in the home. However, such guidance was provided on a one-off basis and during a short interval of time, not as part of a process. When provided in this manner, orientation can raise doubts and harm children, as there is no concern about qualifying family caregivers to develop technical care after discharge.

An integrative review showed lack of consensus regarding the participation of parents in technical or clinical care, in terms of who is responsible for care provision. As the parents' and nurses' roles balance out when caring for the child, the true performance of parents and how comfortable they feel in this role remains ambiguous ${ }^{(10)}$.

A study developed in Iran showed that although health professionals understand the importance of caring for families, they face multiple challenges in planning and incorporating families in their care plans. When determining the effects of a familycentered approach on the satisfaction of hospitalized children's 
parents, the study found increased satisfaction with the health organization and their child's care, especially when the family was involved in the child's care and included in discussions with the health team and decision making, resulting in positive interactions between families and the health team ${ }^{(11)}$.

Care must continue to be given after hospital discharge, which is part of the children's discharge process when they need support at the primary level of care. Families must also be prepared to continue care in the home. Supporting the hospital discharge process corresponds to one of the dimensions of nursing care, whether at the hospital level or at the primary care level in health promotion ${ }^{(12-13)}$.

Training families to conduct care ensures its continuity at home. Thus, this activity is part of the nursing professional's attributions, and depends on how nurses express their role in terms of whether they adopt this form of care $^{(3)}$.

The pediatric unit is permeated by some singularities, such as the intense interaction between nursing teams and the families of hospitalized children, which on one side presents numerous benefits to the sick child, and on the other, can be a source of conflict ${ }^{(14)}$.

The aggressive behavior reported by the nursing professionals represents a barrier to growing close to hospitalized children, making the hospital stay distant and including only the provision of technical care. The result of this interaction can have emotional, ethical, social and pedagogical implications in the child's and family's care.

Thus, meeting the needs of families requires that health professionals and families establish cooperative relationships, reflecting mutual trust and respect ${ }^{(11)}$. Another study developed in Iran found that nurses who practice empathy towards children and their families generate high levels of satisfaction, representing one of the positive aspects of the nurse-family relationship. Furthermore, listening to and presenting proper non-verbal behavior made communication more effective ${ }^{(15)}$.

Nurses must put themselves in patients' shoes to practice and provide high-quality care to families. The findings of this study, especially regarding the relationship of nurses with patients and their families, suggest that hospitals need to apply codes of ethics and disciplinary proceedings when necessary, so that nurses are aware that abusing family members is recognized as a fault by their professional organization ${ }^{(15)}$.

Understanding families and withholding judgment require empathy. Each family has their own way of being, of seeing the world and caring for their children. Professionals must avoid playing the victim and understand that family members may be aggressive when accompanying hospitalized children due to their children's condition, and not necessarily for reasons related with nursing professionals. In this sense, nurses must seek scientific knowledge and develop alterity, one of the principles of the nursing care identity needed to create an identification of this care in the network in which it belongs ${ }^{(3)}$, of care in general. Moreover, they must understand the cultural and social background of families.

Nursing professionals express difficulty in establishing effective communication with families, and are unprepared to deal with the pain and suffering of children. This compromises care provision, as the care provided to children cannot be dissociated from that given to their families ${ }^{(16)}$.
Nursing care actions are based on mobilizing living strength in people and those surrounding them, to compensate for altered capacities due to physical limitations. To enable such action, nursing teams must effectively interact with the families of hospitalized children, so that the illness does not completely absorb nursing care and conflicting interaction is not enhanced ${ }^{(3)}$.

Of the fourteen participants of this study, nine reported having more than one job, a reality that can interfere in the care developed with children and their families.

According to a study in Iran, stress, fatigue and frustration, coupled with uninterrupted long work hours negatively affect nursing attitudes, negatively impacting patients and their families ${ }^{(15)}$.

Length of hospital stay was also reported by the nursing team as a factor hindering interaction and negatively interfering in nursing care. The longer the hospital stay, the more relationship problems between nursing team and families.

Families who stay longer in hospitals absorb the hospital culture, acquiring knowledge about their child's conditions, institutional regulations, and the hierarchy among health team members, and coordinate actions with other mothers in an attempt to provide the best care for their children ${ }^{(1)}$. Even when the hospital is perceived as a strange and unpleasant environment, time spent in the hospital contributes to it becoming customary, unchanging and natural to families ${ }^{(17)}$.

On the other hand, time can also help nursing professionals establish affectionate bonds with hospitalized children and their families, which encourages professionals to spend more time with patients and creates the desire to provide warmth and attention, transcending technical care.

Another study showed that factors such as communication, paternalism, short hospital stays, lack of information from professionals, and lack of time of nurses, especially due to staff shortages, frustration and dissatisfaction with passive roles, fragmentation of care into manual and intellectual work, and the difficulty of integrating nursing and parent roles were considered barriers to positive interaction between families and nursing teams ${ }^{(10)}$.

The relationship between those who provide care and those who receive care can only be meaningful and can only be experienced if: its aim is to discover and recognize the information necessary to provide suitable care, regarding individuals and their illnesses, and resorting to different sources of knowledge to understand its meaning; it is a part of professional actions; enables healthy interactions with patients and those surrounding them; stimulates active participation; promotes coordination with other health professionals; and helps ensure continuity of care and presents important references to assess the quality of the care provided ${ }^{(3)}$.

The participants in this study recognized the importance of the information provided to families of hospitalized children, which should be conveyed in a way that does not generate insecurity and does not foster conflictive interaction.

Nursing teams must recognize the importance of families, as they constitute the unit in which children grow and develop. Considering that families are a constant in the lives of these children, professionals should answer their questions about their children's development, understanding that they have the right to explanations about their children's diagnosis that are complete and adapted to their level of understanding ${ }^{(18)}$. 
The nursing team identified that families often need psychological support to endure and relieve their hospital experience. However, they find themselves playing the role of another professional when they spend more time in contact with families. Nursing professionals cannot play the role of psychologists; however, they realize that by listening to families, they feel well-received and respected in their emotional needs, which facilitates the interaction of this binomial and favors comprehensive and humane care.

The nursing team made concessions for families in the sense of mitigating suffering, reducing stress and improving relationships during the hospital stay. This type of exceptions was understood as a form of caring for the families of hospitalized children, who feel cared for and supported. The team also reported that concessions improve the interaction of families with nursing professionals.

Care identity is based on two antagonistic, yet complementary poles: that of permanence and of constant mutation. Efforts to establish a nursing care and make it identifiable yet not identical consists in accepting and recognizing its permanent characteristics, which must adjust to mutating circumstances ${ }^{(3)}$.

The nursing function in the pediatric inpatient unit was expressed as capable of developing nursing care with families in this setting despite the difficulties in establishing harmonious relationships with families of hospitalized children. In other words, permanent care is directed at the children and technical and scientific care and clinical treatment, whereas mutable care includes the people involved in interactions and situations that occur in the hospital setting ${ }^{(3)}$.

\section{Study limitations}

Limitations of this study include the selection of participants from a single setting, located in the city of Rio de Janeiro, Brazil, which prevents national representivity. In other words, the results cannot be generalized, and further studies are needed in other settings. However, this did not compromise the study's authenticity.

\section{Contributions to the field of nursing}

This study contributes by encouraging critical reflection about the conceptions of nursing teams regarding the families of hospitalized children and their implications for pediatric practice. This can help mitigate conflict generated in these interactions, especially in terms of family involvement and participation in their children's care. Furthermore, this study represents a bibliographical source on hospital care for children, contributing to professional education, in addition to serving as an object of discussion and the starting point for further studies and research groups.

\section{FINAL CONSIDERATIONS}

The conceptions of the nursing team culminated in a dialectic movement which brought forth the official discourse found in the literature in terms of the ideal family, and in contrast, the actual families they encounter in the hospital setting and with whom they interact.

The ideal family was described as that which, during the hospital stay, receives information about their child's clinical condition and treatment, participate in care provision together with the nursing team and finally, receive individualized and singular care. The nursing team must display empathy towards families, understanding their presence as the child's right, as this helps minimize the stress of children and their families in a strange environment and enables family participation in providing care that was already performed at home.

Participants also reported making concessions with regards to companion family members; delegating care that should be the nursing team's responsibility; not training family members for hospital discharge, and establishing conflicting interaction, generating insecurity, aggressiveness and disrespect, demonstrating lack of knowledge.

In conclusion, the nursing team's theoretical knowledge contradicted what is applied in professional practice, according to their conception of the families of hospitalized children. Nursing staff are faced with the challenge of applying such knowledge in practice, contributing to quality of care and involving and training families, minimizing existing conflicts.

The results invite us to a reflection about how care for children has been approached in the pediatric hospital context, in which families are (in)visible. Not involving families in care planning, interventions, decision making and evolution is not part of familycentered care. Therefore, there is still the need for policies and/or programs to include families in the pediatric hospital setting, considering the growth in the number of children affected by chronic diseases or who are technology-dependent.

Thus, family-centered care must be covered in professional education programs, whether at the technical, undergraduate or graduate level, and must also be addressed through refresher courses and by presenting the positive impact that this knowledge brings to professional practice. Moreover, multiprofessional spaces must be established in pediatric hospitals to discuss the relationship with families of hospitalized children, seeking forms to minimize problems and improve quality of care, including the participation of managers to create suitable conditions and infrastructure for the presence of families.

\section{REFERENCES}

1. Souza TV, Oliveira ICS. Interaction of family/companion and nurse team in hospitalized child care: pediatric nursing perspectives. Esc Anna Nery Rev Enferm[Internet]. 2010 [cited 2014 Dec 12];14(3):551-9. Available from: http://www.scielo.br/pdf/ean/v14n3/ v14n3a17.pdf

2. Cruz AC, Angelo M. Cuidado centrado na família em pediatria: redefinindo os relacionamentos. Ciênc Cuid Saúde [Internet]. 2011 [cited 2015 Jan 10];10(4):861-5. Available: http://www.periodicos.uem.br/ojs/index.php/CiencCuidSaude/article/view/18333/pdf

3. Collière MF. Promover a vida: da prática das mulheres de virtude aos cuidados de enfermagem. Lisboa: Lidel, 1999. 
4. Brasil. Ministério da Saúde. Conselho Nacional de Saúde, Comissão Nacional de Ética em Pesquisa. Resolução nº 466, de 12 de dezembro de 2013: diretrizes e normas regulamentadoras de pesquisa envolvendo seres humanos. Brasília (DF): MS; [Internet]. 2013 [cited 2014 Dec 01]. Available from: http://conselho.saude.gov.br/resolucoes/2012/Reso466.pdf

5. Hoffmann MV, Oliveira ICS. Non-directive interview: a possibility of group approach. Rev Bras Enferm [Internet]. 2009 [cited 2014 Nov 11];62(6):923-7. Available from: http://www.scielo.br/pdf/reben/v62n6/a21v62n6.pdf

6. Fontanella BJB, Luchesi BM, Saidel MGB, Ricas J, Turato, ER, Melo DG. Sampling in qualitative research: a proposal for procedures to detect theoretical saturation. Cad Saúde Pública [Internet]. 2011 [cited 2015 Fev 02];27(2):389-94. Available from: http:// www.scielo.br/pdf/csp/v27n2/20.pdf

7. Deslandes SF, Gomes R, Minayo MCS, et al. Pesquisa social: teoria, método e criatividade. 25a ed. Petrópolis: Vozes; 2007.

8. Quirino DD, Collet N, Neves, AFGB. Child hospitalization: nursing conceptions about the mother's companion. Rev Gaúcha Enferm[Internet]. 2010 [cited 2014 Dec 01];31(2):300-6. Available from: http://www.scielo.br/pdf/rgenf/v31n2/14.pdf

9. Xavier DM, Gomes GC, Santos SSC, Lunardi VL, Pintanel AC, Erdmann AL. The family in the Pediatric Unit: living with rules and hospital routines. Rev Bras Enferm [Internet]. 2014 [cited 2015 Mar 02];67(2):181-6. Available from: http://www.scielo.br/pdf/ reben/v67n2/0034-7167-reben-67-02-0181.pdf

10. Pongjaturawit Y, Harrigan RC. Parent participation in the care of hospitalized child in Thai and Western cultures. Issues Compr Pediatr Nurs [Internet]. 2003 [cited 2016 Nov 22];26(3):183-99. Available from: http://onlinelibrary-wiley-com.ez29.capes.proxy. ufrj.br/doi/10.1046/j.1365-2648.2003.02765.x/full

11. Rostami F, Hassan STS, Yaghmai F, Ismaeil SB, Suandi TS. Effects of family-centered care on the satisfaction of parents of children hospitalized in pediatric wards in a pediatric ward in Chaloos in 2012. Electron Physician [Internet]. 2015 [cited 2016 Nov 22];7(2):1078-84. Available from: https://www.ncbi.nlm.nih.gov/pmc/articles/PMC4477769/

12. Silva RVGO, Ramos FRS. The process of releasing a child from the hospital: nursing perceptions concerning limits and potentialities of its part in integral care. Texto Contexto Enferm [Internet]. 2011 [cited 2014 Dec 01];20(2):247-54. Available from: http:// www.scielo.br/pdf/tce/v20n2/a05v20n2.pdf

13. Silva RVGO. Ramos FRS. The nurse work in the discharge of hospitalized children: articulation of basic hospital attention. Rev Gaúcha Enferm [Internet]. 2011 [cited 2014 Dec 01];32(2):309-15. Available: http://www.scielo.br/pdf/rgenf/v32n2/a14v32n2.pdf

14. Sousa LD, Gomes GC, Silva MRS, Santos CP, Silva BT. Family in the paediatrics unit: nursing team's perception about the caring dimension.Cienc Enferm [Internet]. 2011 [cited 2014 Dec 01];17(2):87-95. Available from: http://www.scielo.cl/pdf/cienf/v17n2/ art_10.pdf

15. Loghmani L, Borhani F, Abbaszadeh A. Factors Affecting the Nurse-Patients' Family Communication in Intensive Care Unit of Kerman: a Qualitative Study. J Caring Sci [Internet]. 2014 [cited 2016 Nov 21];3(1):67-82. Available from: https://www.ncbi.nlm. nih.gov/pmc/articles/PMC4134163/

16. Lima AS, Silva VKBA, Collet N, Reichert APS, Oliveira BRG. Relationships established by nurses with families during child hospitalization. Texto Contexto Enferm [Internet]. 2010 [cited 2014 Dec 01];19(4):700-8. Available from: http://www.scielo.br/pdf/ tce/v19n4/13.pdf

17. Gomes GC, Erdmann AL, Oliveira PK, Xavier DM, Santos SSC, Farias DHR. The family living the time during the hospitalization of the child: contributions for nursing. Esc Anna Nery Rev Enferm [Internet]. 2014 [cited 2015 Jan 20]; 18(2):234-40. Available from: http://www.scielo.br/pdf/ean/v18n2/1414-8145-ean-18-02-0234.pdf

18. Barbosa MAM, Balieiro MMFG, Pettengill MAM. Family-centered care in the context of children with disabilities and their families: a reflective review. Texto Contexto Enferm [Internet]. 2012 [cited 2014 Dec 01];21(1):194-9. Available from: http://www. scielo.br/pdf/tce/v21n1/a22v21n1.pdf 